\title{
Flora and vegetation of dry grasslands of Northeastern Ukraine, and problems of diversity conservation
}

\author{
Vladimir Ronkin ${ }^{1, *}$ \& Galina Savchenko ${ }^{1}$
}

Key words: abandonment, cattle grazing, chalky steppe, gully, plant community patch, succession.

Ključne besede: opuščanje, paša goveda, stepa na apnencu, jarek, rastlinska združba, sukcesija.

Received: 29. 05. 2014

Revision received: 29. 01. 2016

Accepted: 24. 02. 2016

Co-ordinating Editor:

Michal Zmihorski

\begin{abstract}
The aim of this study was to describe the flora and vegetation of the grasslands of Northeastern Ukraine and to analyse how the steppe vegetation responds to grazing or its abandonment. We studied two gully systems in the east of the Kharkiv Region: the Regional Landscape Park "The Velykyi Burluk-Steppe" (steppe grasslands on chernozem soils; 10 sites) and the National Nature Park "Dvorichanskyi" (steppe grasslands on chalky outcrops; 5 sites). Longterm monitoring data exist for both these sites starting in 1991, shortly after grazing intensity reduced. We recorded the major grassland plant communities (reflecting their successional status) as well as their dominant species. Tree and scrub encroachment increased after management ceased. We conclude that (i) heterogeneous grazing (including ungrazed patches) in space and time is necessary in order to preserve grassland biodiversity in our study system; (ii) erosion of chalky outcrops (natural erosion as well as driven by cattle grazing) is a key factor promoting the richness of cretaceous species in steppe grassland.
\end{abstract}

\section{Izvleček}

Namen raziskave je bil opisati floro in vegetacijo travišč severovzhodne Ukrajine in ugotoviti, kako se stepska vegetacija odziva na pašo ali njeno opuščanje. Preučevali smo dva sistema jarkov na vzhodu regije Harkov: regionalni krajinski park "The Velykyi Burluk-Steppe" (stepska travišča na černozemu, 10 lokalitet) in narodni park "Dvorichanskyi" (stepska travišča na apnenčastih izdankih, 5 lokalitet). Podatki o dolgoročnem monitoringu obeh lokalitet obstajajo že od leta 1991, kmalu po tem, ko se je zmanjšala intenzivnost paše. Zabeležili smo glavne travniške združbe (ki odražajo sukcesijski status) in njihove dominantne drevesne vrste. Zaraščanje $\mathrm{z}$ drevesi in grmišči se po prenehanju gospodarjenja pospešuje. Zaključili smo, (i) da je heterogena paša (z nepopašenimi zaplatami) v prostoru in času nujna za ohranjanje raznolikosti travišč v proučevanih sistemih in (ii) da je erozija apnenčastih izdankov (naravna in tista, ki jo povzroča govedo) glavni dejavnik za povečevanje številčnosti krednih vrst v stepskih traviščih. 


\section{Introduction}

In the past, a huge part of Ukraine's territory was covered with vast steppes and so was named "the Wild Fields" (Güldenstaedt 1774, Bagalii 1918). The northeastern and the eastern regions of Ukraine along the left bank of the Siverskyi Donets River are richly intersected by river valleys and gullies creating appropriate conditions for steppe vegetation. The original steppe vegetation, patches of which still survive today, is composed of species of both northern steppes of the forest-steppe belt (Stipa pennata, S. tirsa, Carex humilis, Adonis vernalis) and species typical for forb-fescue-feather grass steppes of the genuine steppe belt (Stipa capillata, S. lessingiana, Crambe tatarica, Adonis wolgensis) (Ugrinsky 1918, Levina 1933). Levina (1933) recorded also species typical for shrubby steppes, such as Caragana frutex, Chamaecytisus austriacus, Amygdalus nana, and Cerasus fruticosa, concluding that steppe vegetation of these regions had a transitional character.

Since the late $18^{\text {th }}$ century, the once vast area of steppe has been increasingly transformed by human activity, particularly agriculture. On these lands, a fallow system of agriculture and a three-field system were applied (Güldenstaedt 1774). The old fallow fields were used for hay production and/or as pastures. Since the 1860s, these fallows and remnants of virgin steppe areas have also been increasingly transferred to continuous arable production. The gullies, however, could not be ploughed and that is why they became the only refuge for specialist steppe plants and animals. As a consequence, these dry grasslands on gullies are recognized as ecosystems of high importance for the steppe biodiversity where many protected and rare species of flora and fauna have survived. The grasslands covering the gullies were formed by livestock grazing (mainly cattle and sheep, sometimes horses). However, after 1990s, the intensity of grazing significantly decreased. As a result, all stages of pasture degradation can be observed in the area now - from feather grass to bulbous bluegrass stage, as well as the recovery of plant communities after grazing pressure reduces.

Long-term ecological monitoring has been conducted in these gully areas since 1991, providing us with the opportunity to document the habitat transformation taking place in the region. The aims of the current study were (1) to describe flora and vegetation of dry grasslands of the northeastern and the eastern regions of Ukraine before and after the abandonment of cattle grazing; (2) to describe the successional processes taking place in the region; and (3) to link vegetation responses to grazing and its abandonment in order to derive recommendations for the conservation of dry grassland biodiversity.

\section{Materials And Methods}

\section{The Land Use History}

Since the late $18^{\text {th }}$ century, the agricultural use of gullies was based on low-intensity livestock grazing. The period from 1800 to the abolition of serfdom in 1861 was characterised by the development of commercial livestock breeding. Between 1861 and 1913 the cattle population slightly increased while the sheep population halved (Zhivotnovodstvo SSSR, 1940). During the First World War, the livestock population in Kharkiv Region reduced dramatically, but between 1918 and 1928 the number of the cattle recovered to the pre-war number, then decreased by a factor of 2.3 by the end of 1930s. In the 1950s the USSR government introduced a policy of agricultural productivity growth. As a result, the area of arable land and the number of livestock increased considerably, while the area of hayfields and pastures reduced. As a consequence, the grazing pressure on the gullies and the valley bottom meadows was greatly increased. To avoid soil erosion, trees and shrubs were planted over vast areas of the USSR. In the study area, such artificial plantations included both native (Pinus silvestris, Quercus robur, Fraxinus excelsior) and alien (Robinia pseudoacacia, Acer negundo, Elaeagnus argentea) species.

Livestock grazing began to decrease again after 1990s. From 1995-2005, the livestock population decreased by a factor of four due to the effects of the dissolution of the USSR. Dead plant material began to accumulate on the ungrazed areas of meadows and steppes, and extensive fires were recorded in the study area, including the areas of chalky steppe. From 2005, confinement feeding of cattle began to replace the previous system of traditional pastoralism with herders. In 2015, the grazed area decreased dramatically, but the area of arable land did not change. At present, arable crop rotation is the dominant land use type in Northeastern Ukraine.

In 1994, the Parliament of Ukraine resolved to increase the area of land under nature protection. New reserves were created, including new forms of protected area for Northeastern Ukraine such as nature parks. There are two types of nature parks in Ukraine: national nature parks and regional landscape parks. National nature parks must contain zones free of human interference, and may also have zones of agricultural use. In regional parks, agricultural use generally continues as was practiced before the creation of the park. In 1999-2009, three national nature parks and four regional landscape parks were created in Northeastern Ukraine. 


\section{Study Area}

The research was carried out in northeastern part of Kharkiv Region (Northeastern Ukraine, Figure 1), which is considered a border region between forest-steppe and genuine steppe zones. Mean annual rainfall is 480 $520 \mathrm{~mm}$; the annual mean temperature is from $6.0^{\circ} \mathrm{C}$ to $7.4{ }^{\circ} \mathrm{C}$ with summer temperatures often exceeding $36^{\circ} \mathrm{C}$ and mean January temperature ranging from $-6.8^{\circ} \mathrm{C}$ to $-8.5^{\circ} \mathrm{C}\left(\min -35^{\circ} \mathrm{C}\right)$. meet the targets of biodiversity conservation, i.e. it cannot be more intensive than it was before the foundation of the parks.

The Regional Landscape Park (RLP) "The Velykyi Burluk-Steppe" (the first site) represents typical grasslands on chernozem soils at an altitude 105-200 m a.s.l. The total area of the park is 2043 hectares. It includes 1638 ha of grasslands (about 1390 ha of steppes, 248 ha of meadows) and 400 ha of woodland. In 2005, 10\% of the area of these grasslands was subjected to heavy graz-

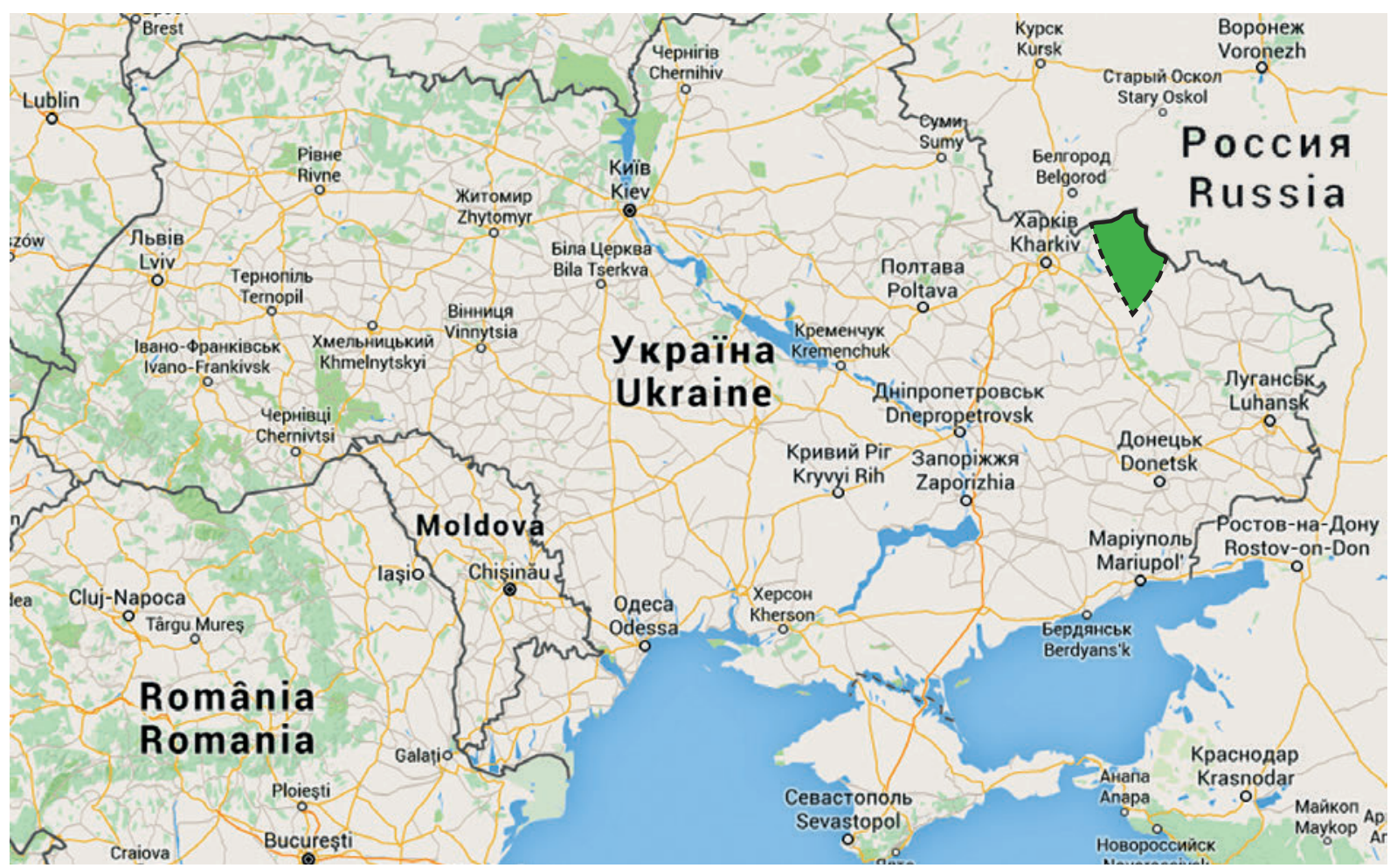

Figure 1: Location of the study area (red dashed line) (Kharkiv Region, Northeastern Ukraine).

Slika 1: Lokacija obravnavanega območja (obkroženo z rdečo) (regija Harkov, severovzhodna Ukrajina).

The proportion of arable land in the study region is $68.8 \%$ of the total area; grasslands cover $16.5 \%(13.7 \%$ pastures and $2.8 \%$ meadows), woodlands $-8.1 \%$, settlements and roads $-3.7 \%$, wetlands and water $-1.3 \%$, land without vegetation cover $-0.9 \%$, gardens $-0.7 \%$.

After general zoological and botanical investigations of the whole study area, we chose a model site that contains all typical grassland habitats of the wider area excluding chalk grasslands, and monitoring began in 1991. Later, we extended our studies to the chalk grasslands, choosing the second model site in 2000. Now both sites (Figure 2) have the status of Nature Parks. Within these parks, the traditional land use (grazing and mowing) is restricted to ing, another $15 \%$ of the area had light, moderate, or variable grazing pressure. A permanent study plot (an area of about 290 ha) was set up in a broad gully system on the right bank of the Velykyi Burluk River. It includes gullies with different grazing histories.

The National Nature Park (NNP) "Dvorichanskyi" (the second site) contains mainly grasslands on chalky outcrops. It is located in the Oskil River valley (altitude from $75 \mathrm{~m}$ to $183 \mathrm{~m}$ a.s.l.). The park has an area of 3131 hectares including 2216 ha of grasslands (1124 ha of steppes, 1073 ha of meadows) and 798 ha of woodland. It is the newest of the parks protecting chalky vegetation in Ukraine (it has 402 ha of chalky steppes and 172 ha of chalky outcrops with specific vegetation); it is one of the largest continuous refuges for steppe flora in Northeastern Ukraine. The chalky steppe occupies the hilly landscape of the Oskil River right bank. The bottomland-meadow 


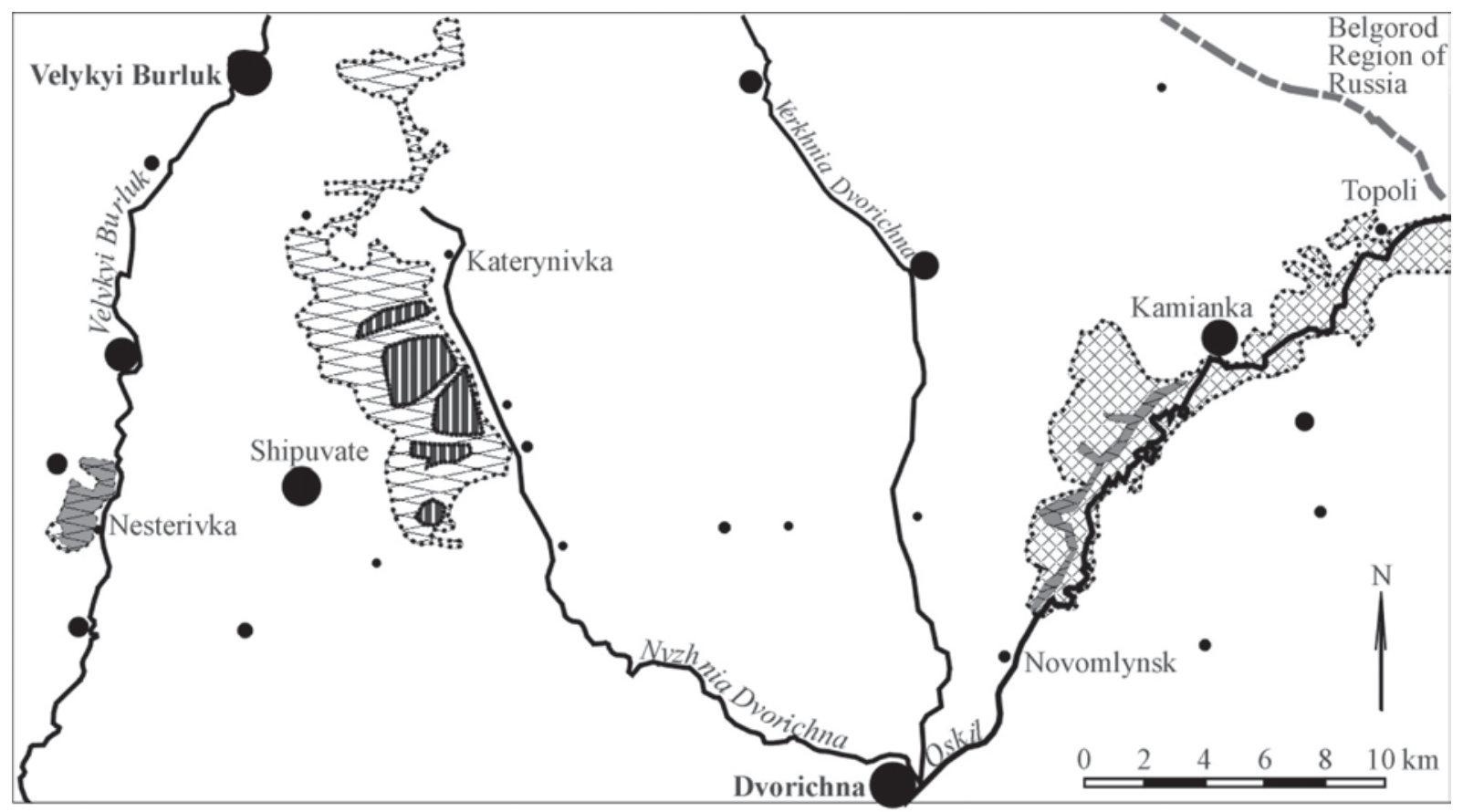

Legend: - villages; - - frontier; $\Theta$ - "The Velykyi Burluk-Steppe" RLP; $\bigotimes$ - the "Dvorichanskyi" NNP; (II) - arable land.

Figure 2: Location of the Regional Landscape Park (RLP) "The Velykyi Burluk-Steppe" and the National Nature Park (NNP) "Dvorichanskyi" in Kharkiv Region (Northeastern Ukraine). The permanent study plots are shaded grey. Location of the Nesterivka Village: $49^{\circ} 55^{\prime} 19^{\prime \prime} \mathrm{N}$; $37^{\circ} 18^{\prime} 46^{\prime \prime} \mathrm{E}$.

Slika 2: Lokacija regionalnega krajinskega parka (RLP) "The Velykyi Burluk-Steppe" in narodnega parka (NNP) "Dvorichanskyi” v regiji Harkov (severovzhodna Ukrajina). Stalne raziskovalne ploskve so označene s sivo. Lokacija vasi Nesterivka: $49^{\circ} 55^{\prime} 19^{\prime \prime}$ S; 37 $18^{\circ}$ ' 46" V.

is partially under light grazing pressure; the chalky steppe is ungrazed. A permanent study plot was set in a gully system (an area about $200 \mathrm{ha}$ ). According to zonation regime, which was applied after the Park foundation, the site covers two zones. The vegetation of chalky outcrops and chalky steppe are the zone under strict protection; the communities of common steppe and meadow lay in the zone of regulated recreation.

\section{Data collection}

Data were collected in the study site "The Velykyi Burluk-Steppe" from 1992-2014 at the permanent study plot in six gullies. Ten habitats (as combinations of grazing intensity and relief) were common at the plot in 1992. The large-scale variation in grazing intensity across the gully means that it was possible to sample all plant communities specific to the different grazing intensities under given conditions, as one large unbroken plot (Figure 3). Thus, ten sample plots containing the grassland communities typical for the specific study period were selected within the permanent study plot. In 1992, ten communities were identified; sometimes one plot in- cluded one or two communities per plot, sometimes two plots were occupied mainly by a single community. Data were collected using 1.0 and $10.0 \mathrm{~m}^{2}$ quadrats within a given plant community patch (a nested method), and repeated twice a year (Figure 3 ). In a given plant community patch, we placed a $1 \times 1 \mathrm{~m}$ quadrat and recorded species of vascular plants that occurred within it. Around this quadrat, we surveyed a larger quadrat of 10 square meters $(3.16 \times 3.16 \mathrm{~m})$, recording the species and their estimated percentage cover. Then, within the contours of the given plant community patch, we completed the list of species and estimated abundance of added species using the Braun-Blanquet scale.

Data were collected between early May and late August. The first plots were surveyed in the period of bulbous bluegrass flowering (May), the second survey was during the main flowering period in May-June, and the last survey was in August (goldilocks blossoming).

Within the sample plots, we collected the following data: (1) species composition of vascular plants, (2) coverage of the species (3) total live vegetation cover, (4) number of the species per $1 \mathrm{~m}^{2}$, (5) height of the highest vegetation layer, and (6) the phytomass $\left(\mathrm{g} / \mathrm{m}^{2}\right)$ of total 

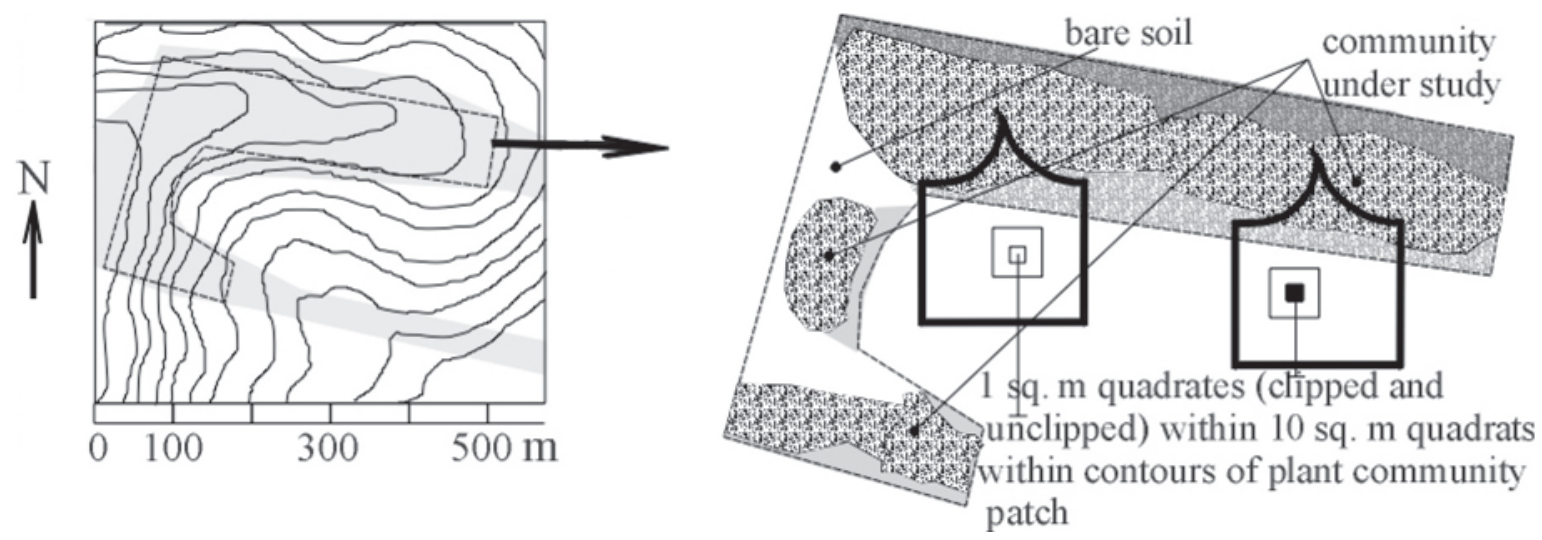

Figure 3: Fragment of the permanent study plot in "The Velykyi Burluk-Steppe", one of the sample plots that corresponds to overgrazing shown by grey color on the map; and design of the data collection.

Slika 3: Del stalne poskusne ploskve v "Velykyi Burluk-Steppe”. Ena od vzorčnih ploskev z intenzivno pašo, ki so prikazane s sivo na zemljevidu, in načrt zajema podatkov.

and of dominant species recorded by clipping and determining the dry weight of the aboveground living vascular plants on $1 \mathrm{~m}^{2}$. For each plant community, phytomass was measured 9 times over a 5 year period and the nested method was applied eighteen times at the same time. The following ten communities were sampled over the years 1992-1996: Stipa capillata+Festuca valesiaca; Galatella villosa; Fragaria viridis; Festuca rupicola; Calamagrostis epigeios; Carex praecox; Festuca valesiaca (early stages of pasture degradation); Festuca valesiaca (midstage pasture degradation); Poa angustifolia and Poa bulbosa/Polygonum aviculare (May-June/June-August at the same sample plot).

In following years, species composition and abundance were recorded without clipping. We registered changes in the list of plant communities within the sample plots and at the whole permanent study plot level. The communities, as well as a new communities that appeared during succession (in place of the studied ones, too), were studied according to the method described above. In 1997-1999, the clipping-method was applied in patches dominated by Carduus acanthoides; in 2005-2009 in patches dominated by Agrimonia eupatoria; and in 2010-2014 dominated by Stipa capillata+Festuca valesiaca. In total, we recorded plant cover in 111 clipped quadrats of $1 \mathrm{~m}^{2}$ and 221 double-nested plots. We also mapped the vegetation and the grazing intensity within the permanent study plot.

In 2001, five habitats were selected according to the degree of soil development on the chalky outcrops in the permanent study plot in the Dvorichanskyi NNP, including three gullies: 1) white creeping chalk; 2) white slowcreeping chalk; 3) grey chalk with total living cover less than $50 \%$; 4) grey chalk with total living cover more than $50 \%$; 5) chalk covered with slight layer of soil, living cover more than $50 \%$. As a rule, the variation in soil layer thickness with gully relief means that it is not possible to delineate a single, contiguous plot including typical examples of all communities present. Sample plots were therefore selected as large patches of communities over the whole permanent study site linked to the degree of soil development. We recorded 18 sample plots of 9 communities (two per community), which we sampled once per year during the flowering period of the dominant species. We recorded plant cover in 54 double-nested plots (six per plant community), i.e. $1 \mathrm{~m}^{2}$ and $10 \mathrm{~m}^{2}$ quadrats within a $100 \mathrm{~m}^{2}$ quadrat in a given plant community patch. In each quadrat size, we recorded the following characteristics: number of vegetation layers, height of the highest grass layer, live vascular plant cover in percent, percentage cover of species, the species composition and number of the species. Data were collected in 2001-2014 in a sampling period between early May and late August. The first plots were recorded in the flowering period of Androsace koso-poljanskii, in May; the next samples were collected during the main flowering period in May-July; and the last samples were taken in August (Artemisia hololeuca flowering). Data on communities dominated by Artemisia hololeuca and Artemisia hololeuca + Thymus cretaceus were sampled in 2001-2006; those dominated by Hedysarum grandiflorum; Astragalus albicaulis and Carex humilis in 2007-2012. Two communities dominated by Stipa pennata and Stipa pulcherrima, which appeared throughout the site as new communities, were studied in 2009-2014.

The degree of pasture degradation was recorded using the Ramensky (1971) scale: stage I corresponds to the initial community, followed by II (early), III (mid) and IV (late) and V (latest) stage. The first and second stages of pasture degradation correspond to light grazing, the second 
and third stages to moderate grazing, the third and fourth to heavy grazing, and the fifth to overgrazing. The compositional similarity of the habitats with different grazing intensities was estimated using the Jaccard' coefficient, $\mathrm{K}_{\mathrm{I}}=\mathrm{C} /$ $\mathrm{A}+\mathrm{B}-\mathrm{C}$, whereby $\mathrm{C}=$ the number of species registered in both habitats, $A=$ number of species in the first habitat, and $\mathrm{B}=$ number of species in the second habitat.

The species were grouped on the basis of humidity according to Gorelova (2002), i.e. from xerophytes through xeromesophytes, etc. to hygromesophytes.

\section{Results}

\section{Study site "The Velykyi Burluk- Steppe".}

\section{Flora and vegetation}

The vegetation of the park is characterised by both communities of meadows and forb-fescue-feather grass steppe. Our list of grasses, forbs and shrubs of gully steppe and meadows on gully bottoms of the park includes 331 species of vascular plants. 291 species were registered in the permanent study plot, including 31 species of rare and protected plants $(5$ species are listed in the Red Book of Ukraine). The majority of dicot species were in the following families: Asteraceae (51 species), Fabaceae (27), Lamiaceae (23), Brassicaceae (18), Rosaceae (16), Caryophyllaceae (15), Scrophulariaceae (13) and Ranunculaceae (11). The most frequently recorded graminoids were fescue (Festuca valesiaca, F. rupicola), feather grass (Stipa capillata), bluegrass (Poa angustifolia, P. bulbosa, P. pratensis), June grass (Koeleria cristata), meadow brome (Bromopsis riparia) and sedge (Carex praecox).

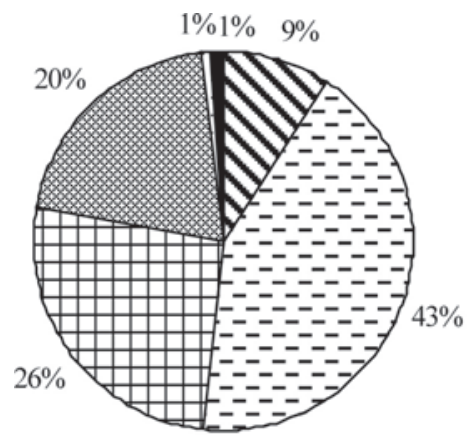

\section{$\mathbf{\nabla}$ Xerophytes \\ $\Xi$ Xeromesophytes \\ 田 Mesoxerophytes \\ Mesophytes \\ Mesohygrophytes \\ Hygromesophytes}

Figure 4: Proportions of different ecological groups on the basis of humidity variation in the gullies of the permanent study plot "The Velykyi Burluk-Steppe“.

Slika 4: Delež različnih ekoloških skupin na podlagi variabilnosti vlažnosti v jarkih na stalnih poskusnih ploskvah v "Velykyi Burluk-Steppe“.
According to the variation in humidity in the gullies, we found six groups of species (from xerophytes to hygromesophytes); the majority of species (123 species) were xeromesophytes (Figure 4).

Communities of Festuca valesiaca, Stipa capillata, Carex praecox, Caragana frutex, Calamagrostis epigeios and Poa angustifolia were the most typical for the study site (as well as for the whole study area). On the permanent study plot, Caragana frutex formed dense monodominant stands; their patches of small size occur throughout the plot. Because all the steppe plateaus were once ploughed, the original communities had remained only in the gullies. Figure 5 shows the typical pattern (till the beginning of the $21^{\text {st }}$ century) of management in the study area by the example of the permanent study plot. Figure 6 shows a mosaic of the typical plant communities in the gullies of the ungrazed zone of the permanent study plot as well as the characteristic species of dominants in the communities.

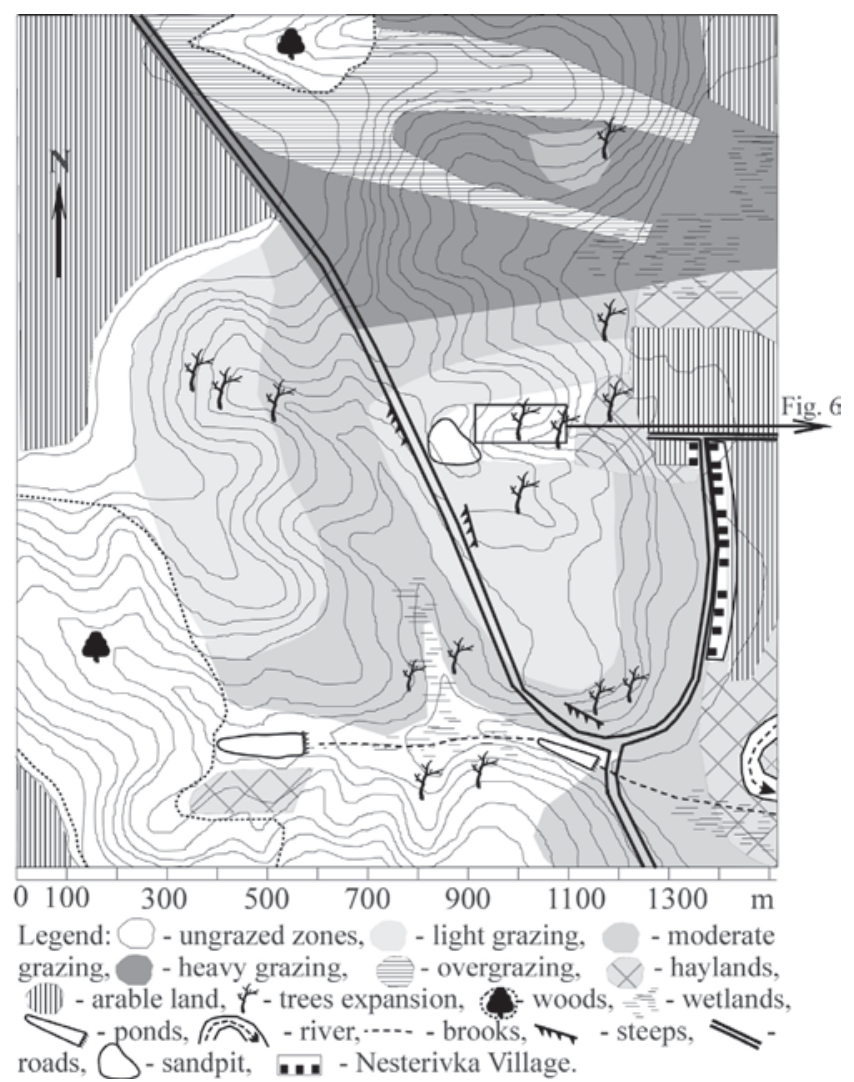

Figure 5: Fragment of the permanent study plot "The Velykyi Burluk-Steppe" (location of the Nesterivka Village: 49 55' 19" N; $37^{\circ} 18^{\prime} 46^{\prime \prime}$ E). 1992-2000 years. Spatial relationships between particular habitats and grazing zones.

Slika 5: Del stalne poskusne ploskve "Velykyi Burluk-Steppe" (lokacija vasi Nesterivka: $49^{\circ} 55^{\prime} 19^{\prime \prime}$ S; 37 18' 46" V). Leta 1992-2000. Prostorski odnosi med določenimi habitati in pašnimi območji. 


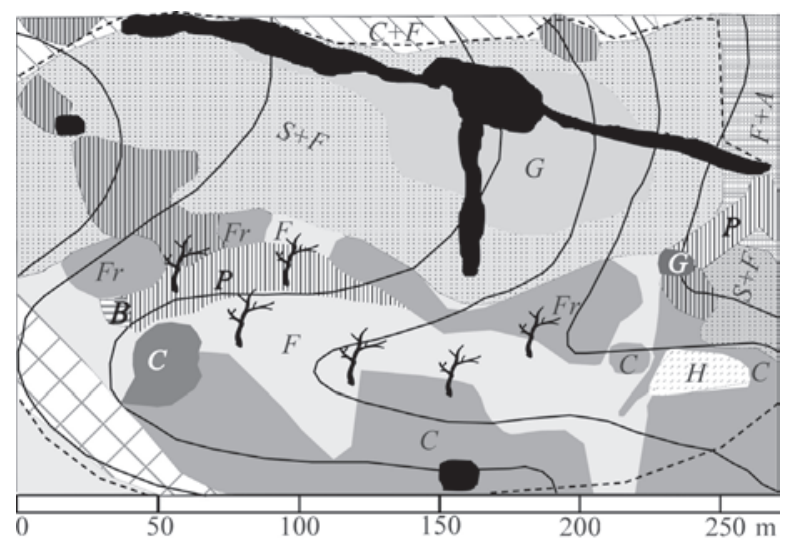

Legend: $\bar{t}$-trees; $\overline{\mathrm{C}}+F$-Chamaecytisus austriacus + Festuca rupicola; 101|if - Chamaecytisus austriacus; - - Caragana frutex; $S+F-$ Stipa capillata + Festuca valesiaca; $F+A-$ Festuca rupicola + Agrimonia eupatoria; $G$-Galatella villosa; $\|$ P - Poa angustifolia; $G-$ Galium boreale; $F$ - Festuca rupicola; $F$ - Fragaria viridis; $\mathcal{B}-$ Bromopsis inermis; $\quad C$ - Carex praecox; $\quad C$ - Calamagrostis epigeios: (A) -Artemisia campestris; (H) - Hieracium pilosella.

Figure 6: Location of the different plant communities in the gully of the ungrazed zone (dashed line) of the permanent study plot "The Velykyi Burluk-Steppe“.

Slika 6: Lokacije različnih rastlinskih združb v jarku v nepašnem območju (črtkano) na stalni poskusni ploskvi "Velykyi Burluk-Steppe“.

\section{Effects of grazing on the vegetation}

From the mid 1950s all the gullies began to be grazed with increasing the pressure on the area till the beginning 1990s, when the study of this area began. All the stages of pasture degradation were present at this point. Gully relief causes localization of meadow- and steppe vegeta- tion (mainly on the basis of humidity variation). The intensity of grazing also depends on relief. The meadow vegetation of gully bottoms or gentle slopes is preferred by cattle, whilst steep slopes are avoided. Pastures close to villages are grazed first, and grazing intensity has been historically heavy here. Recently, these areas remain under heavy grazing. Historically lightly grazed gullies have not been grazed from 1991-1993 until the present. Historically moderately grazed gullies have recently been lightly grazed or ungrazed.

The vegetation of ungrazed steep slopes, slopes with high insolation and washed chernozem soils supported communities of Stipa capillata+Festuca valesiaca + forbs and Galatella villosa. Places with richer soils were occupied by the shrubs Chamaecytisus austriacus, Caragana frutex, and patches of Fragaria viridis, Festuca rupicola, Calamagrostis epigeios, and Carex praecox (Table 1). Calamagrostis epigeios and Carex praecox occupied north facing slopes; patches of Fragaria viridis and Festuca rupicola were registered mostly at the base areas of slopes, and gully bottoms. Among the communities of the gully bottom, patches of meadow community Poa angustifolia+wet meadow forbs were also recorded.

Lightly grazed slopes were covered with patches of communities Festuca valesiaca+Stipa capillata, Festuca valesiaca+Bromopsis riparia. They mainly represented the early stage of pasture degradation of the fescue-feather grass communities. Patches of Hieracium pilosella were recorded in the same habitats as the community Galatella villosa in the ungrazed zone (i.e. on steep slopes, slopes with high insolation and washed chernozem). Chamae-

Table 1: The main grass communities and typical habitats of gullies ungrazed since 1991-1993 (1992-1996): their dominant species, cover values, number of species, and diversity indexes. The permanent study plot "The Velykyi Burluk-Steppe".

Tabela 1: Glavne travniške združbe in značilni habitati jarkov, kjer niso pasli v letih od 1991 do 1993 in v obdobju med letoma 1992 in 1996: dominantne vrste, pokrovne vrednosti, število vrst in indeksi raznolikosti. Stalna poskusna ploskev "Velykyi Burluk-Steppe".

\begin{tabular}{|c|c|c|c|c|c|c|}
\hline Habitats* & $\begin{array}{l}\text { Total living } \\
\text { cover, } \\
\text { mean } \pm \text { s.d. } \% \\
\end{array}$ & $\begin{array}{l}\text { Dominant species and } \\
\text { their percentage cover, } \\
\text { mean } \pm \text { s.d. } \% \\
\end{array}$ & $\begin{array}{l}\text { Mean proportion of dominant } \\
\text { species in the total } \\
\text { above ground living mass }\end{array}$ & $\begin{array}{l}\text { № of species per } \\
1 \mathrm{~m}^{2} ; 10 \mathrm{~m}^{2} ; \text { and } \\
\text { per plant patch }\end{array}$ & $\begin{array}{l}\text { Shannon' } \\
\text { index }\end{array}$ & $\begin{array}{l}\text { Margalef' } \\
\text { index }\end{array}$ \\
\hline $\begin{array}{l}\text { Dry places, } \\
\text { any soils }\end{array}$ & $53 \pm 20$ & $\begin{array}{l}\text { Stipa capillata }+ \text { Festuca } \\
\text { valesiaca } ; 32 \pm 10\end{array}$ & $73 \%$ & $21 ; 28 ; 35$ & 1.858 & 4.849 \\
\hline $\begin{array}{l}\text { Dry places, } \\
\text { poor washed soils }\end{array}$ & $58 \pm 10$ & $\begin{array}{l}\text { Galatella villosa } \\
\qquad 20 \pm 9\end{array}$ & $27 \%$ & $19 ; 28 ; 35$ & 2.496 & 6.252 \\
\hline $\begin{array}{l}\text { More rich soils, } \\
\text { any places }\end{array}$ & $92 \pm 6$ & $\begin{array}{l}\text { Fragaria viridis; } \\
\qquad 62 \pm 14\end{array}$ & $45 \%$ & $23 ; 27 ; 32$ & 1.714 & 5.463 \\
\hline $\begin{array}{l}\text { Gully bottoms, } \\
\text { rich soils }\end{array}$ & $65 \pm 10$ & $\begin{array}{l}\text { Festuca rupicola } \\
\qquad 40 \pm 13\end{array}$ & $53 \%$ & $26 ; 36 ; 52$ & 2.340 & 7.799 \\
\hline $\begin{array}{l}\text { North facing } \\
\text { slopes, any soils }\end{array}$ & $36 \pm 8$ & $\begin{array}{l}\text { Calamagrostis epigeios; } \\
\qquad 20 \pm 5\end{array}$ & $80 \%$ & $16 ; 31 ; 41$ & 0.622 & 6.363 \\
\hline $\begin{array}{l}\text { North facing } \\
\text { slopes, any soils }\end{array}$ & $65 \pm 17$ & $\begin{array}{l}\text { Carex praecox; } \\
51 \pm 24\end{array}$ & $74 \%$ & $17 ; 29 ; 47$ & 1.183 & 6.668 \\
\hline
\end{tabular}

* In each plot $\mathrm{n}=18$ for the cover values and $\mathrm{n}=9$ for the phytomass values. 
cytisus austriacus was recorded not as mono-dominant but as co-dominant in the community of Chamaecytisus austriacus+Festuca rupicola. Patches of shrubs Caragana frutex, as well as patches of Festuca rupicola, loose-bunch graminoids (Calamagrostis epigeios, Carex praecox) and Fragaria viridis were present under regular light to moderate grazing. They were present at the early stage of pasture degradation and remained until the mid stage, whilst the Poa angustifolia+wet meadow forbs community remained until the late stage.

The community of Festuca valesiaca+upland-meadow forbs represented the mid stage of pasture degradation of the fescue-feather grass communities. It occupied gentle slopes under moderate grazing and was present on steep slopes under the same grazing intensity as small separate patches among vegetation of the later stages and bare soil. On steep slopes under moderate grazing, the mid, late and the latest stages of pasture degradation were observed simultaneously as patches and strips among paths with bare soil. Patches of Hieracium pilosella has been present in places with high insolation and washed soils. Chamaecytisus austriacus was found among species of the community of Festuca rupicola. Fragaria viridis was not registered as dominant but was present in the list of species of the communities Festuca rupicolalF. valesiaca.

None of the communities listed above remained at the late stage of pasture degradation (excluding Poa angustifolia+wet meadow forbs). Gentle slopes and gully bottoms under heavy grazing were covered with the meadow community of Poa angustifolia+upland-meadow forbs. The steep slopes under moderate grazing were covered partly with this community. Besides, the moist places of the gully bottoms were occupied with patches of meadow communities of Poa angustifolia/P. pratensis+wet meadow forbs (but they had small areas in comparison with the total area under study). Poa angustifolia is a fodder loose-bunch grass that responds positively to heavy grazing and displaces the steppe bunch grasses during

Table 2: The main grass communities of grazed gullies and gullies ungrazed since 2005 of the permanent study plot "The Velykyi Burluk-Steppe": their dominant species, cover values, number of species, and diversity indexes.

Table 2: Glavne travniške združbe pašnih jarkov in jarkov na stalni poskusni ploskvi "Velykyi Burluk-Steppe”, kjer niso pasli od leta 2005: dominantne vrste, pokrovne vrednosti, število vrst in indeksi raznolikosti.

\begin{tabular}{|c|c|c|c|c|c|c|}
\hline $\begin{array}{l}\text { Successional status } \\
\text { (and the sampling years) }\end{array}$ & $\begin{array}{c}\text { Total } \\
\text { living } \\
\text { cover, } \\
\text { mean } \pm \text { s.d., \% }\end{array}$ & $\begin{array}{l}\text { Dominant species } \\
\text { and their } \\
\text { percentage cover, } \\
\text { mean } \pm \text { s.d., } \%\end{array}$ & $\begin{array}{l}\text { Mean proportion of } \\
\text { dominant species in } \\
\text { the total aboveground } \\
\text { living mass }\end{array}$ & $\begin{array}{l}\text { № of species } \\
\text { per } 1 \mathrm{~m}^{2} \text {; } \\
10 \mathrm{~m}^{2} \text { and } \\
\text { per plant patch }\end{array}$ & $\begin{array}{l}\text { Shannon' } \\
\text { index }\end{array}$ & $\begin{array}{l}\text { Margalef } \\
\text { index }\end{array}$ \\
\hline $\begin{array}{l}\text { Early stage of pasture deg- } \\
\text { radation* }(1992-1996)\end{array}$ & $66 \pm 9$ & $\begin{array}{l}\text { Festuca valesiaca; } \\
\qquad 42 \pm 17\end{array}$ & $56 \%$ & $18 ; 32 ; 53$ & 1.984 & 7.814 \\
\hline $\begin{array}{l}\text { Mid stage of pasture } \\
\text { degradation } \\
(1992-1996)\end{array}$ & $55 \pm 10$ & $\begin{array}{l}\text { Festuca valesiaca; } \\
\qquad 46 \pm 12\end{array}$ & $48 \%$ & $12 ; 21 ; 70$ & 2.383 & 10.593 \\
\hline $\begin{array}{l}\text { Late stage of pasture } \\
\text { degradation } \\
(1992-1996)\end{array}$ & $88 \pm 11$ & $\begin{array}{l}\text { Poa angustifolia; } \\
\quad 74 \pm 15\end{array}$ & $37 \%$ & $12 ; 16 ; 30$ & 2.163 & 5.269 \\
\hline $\begin{array}{l}\text { Latest stage of pasture } \\
\text { degradation, } \\
\text { May (1992-1996) }\end{array}$ & $61 \pm 19$ & $\begin{array}{l}\text { Poa bulbosa } \\
\quad 60 \pm 19\end{array}$ & $90 \%$ & $9 ; 11 ; 20$ & 0.284 & 2.536 \\
\hline $\begin{array}{l}\text { Latest stage of pasture } \\
\text { degradation, June-July } \\
(1992-1996)\end{array}$ & $64 \pm 15$ & $\begin{array}{l}\text { Polygonum aviculare; } \\
\qquad 58 \pm 15\end{array}$ & $75 \%$ & $6 ; 8 ; 12$ & 1.074 & 1.991 \\
\hline $\begin{array}{l}\text { Abandonment after the } \\
\text { latest stage of pasture } \\
\text { degradation (1997-1999) }\end{array}$ & $82 \pm 16$ & $\begin{array}{l}\text { Carduus acanthoides; } \\
\qquad 71 \pm 12\end{array}$ & $99 \%$ & $8 ; 13 ; 27$ & 0.102 & 4.830 \\
\hline $\begin{array}{l}\text { Abandonment after late } \\
\text { and mid stages of pasture } \\
\text { degradation }(2005-2009)\end{array}$ & $93 \pm 4$ & $\begin{array}{l}\text { Agrimonia eupatoria; } \\
\qquad 73 \pm 7\end{array}$ & $81 \%$ & $16 ; 24 ; 54$ & 1.154 & 8.291 \\
\hline $\begin{array}{l}\text { Abandonment after early } \\
\text { stage of pasture degrada- } \\
\text { tion (2010-2014) }\end{array}$ & $35 \pm 5$ & $\begin{array}{l}\text { Stipa capillata+ } \\
\text { Festuca valesiaca; } \\
\qquad 20 \pm 6\end{array}$ & $68 \%$ & $15 ; 17 ; 48$ & 2.196 & 10.298 \\
\hline
\end{tabular}

* In each successional status $\mathrm{n}=18$ for the cover values and $\mathrm{n}=9$ for the phytomass values, excluding Carduus acanthoides, where it was $\mathrm{n}=5$ and $\mathrm{n}=3$, respectively. 
the late stage of pasture degradation. The vegetation at this stage (mainly a mix of Poa angustifolia, Achillea millefolium, Plantago media, Festuca valesiaca, Elymus repens, Artemisia austriaca) is regularly grazed by cattle down to $7-10 \mathrm{~cm}$ above the soil surface but includes also tall-growing free-standing Eryngium campestre, Carduus acanthoides and other unpalatable species.

The cover of Poa bulbosa with the spring-flowering species Gagea pusilla, Ceratocephala testiculata, Holosteum umbellatum displaces community of Poa angustifolia+upland-meadow forbs on the latest stages of pasture degradation and represents overgrazed plots in spring; Polygonum aviculare occupies the same plots in summer and autumn (Table 2). According to our observations, the overgrazing was caused by daily driving of cattle from their stall to the nearest pasture (300 individuals, four times per day from 1-10 May to 20-30 September, yearly). Flat dry habitats were covered with Poa bulbosal Polygonum aviculare, the steep slopes lost the vegetation completely. All the other stages of pasture degradation were caused by various intensity of pasturing in different habitats. The same stocking rate had dif- ferent effects in dependence on slope steepness. On the steep slopes, later stages of pasture degradation were observed, than on the gentle ones at the same loading.

There is a compositional difference in plant species between the vegetation of the gullies, which have similar relief and soil but different histories of grazing pressure. The sample compositional similarity was 0.3 (Jaccard' coefficient) for the lightly-heavily grazed gullies, 0.5 for the lightly-moderately grazed and 0.4 for the moderately-heavily grazed. The highest diversity scores were registered in Festuca valesiaca community at mid stages of pasture degradation; at the next stages (Poa angustifolia and $P$. bulbosa/Polygonum aviculare stages) the scores decreased sharply. The number of species was higher in plant communities under light and moderate (early and mid stages of pasture degradation) compared to heavy grazing pressure and overgrazing (late and the latest stages of pasture degradation) (Table 2).

The share of mesophytes (number and cover) was similar in historically lightly and moderately grazed gullies (Table 3); it was higher in heavy grazed gullies because these gullies had the greatest areas of meadow commu-

Table 3: Proportion of ecologically different species relative to grazing intensity in the gullies of the permanent study plot "The Velykyi Burluk-Steppe" (290 hectares) in 1992-1996.

Tabela 3: Delež ekološko različnih vrst v odvisnosti od intenzivnosti paše v jarkih na stalni poskusni ploskvi "Velykyi BurlukSteppe" (290 hektarjev) med 1992-1996.

\begin{tabular}{|c|c|c|c|c|c|c|}
\hline \multirow[b]{2}{*}{$\begin{array}{l}\text { Ecological features of } \\
\text { species; } \\
\text { duration of life cycle }\end{array}$} & \multicolumn{2}{|c|}{ Historically lightly grazed } & \multicolumn{2}{|c|}{ Moderate grazing } & \multicolumn{2}{|c|}{ Heavy grazing and overgrazing } \\
\hline & $\begin{array}{c}\text { № of species; } \\
\text { percent }\end{array}$ & $\begin{array}{l}\text { Mean cover } \\
\text { of this species } \\
\text { group; percent }\end{array}$ & $\begin{array}{c}\text { № of species; } \\
\text { percent }\end{array}$ & $\begin{array}{l}\text { Mean cover } \\
\text { of this species } \\
\text { group; percent }\end{array}$ & $\begin{array}{c}\text { № of species; } \\
\text { percent }\end{array}$ & $\begin{array}{l}\text { Mean cover } \\
\text { of these species } \\
\text { group; percent }\end{array}$ \\
\hline Xerophytes & $103 ;(77.4)$ & $55.3 ;(89.8)$ & $101 ;(78.9)$ & $48.5 ;(88.1)$ & $62 ;(72.1)$ & $61.6 ;(81.7)$ \\
\hline Mesophytes & $30 ;(22.6)$ & $6.3 ;(10.2)$ & $27 ;(21.1)$ & $6.5 ;(11.9)$ & $24 ;(27.9)$ & $13.8 ;(18.3)$ \\
\hline Total & $133 ;(100.0)$ & 61.6; (100.0) & $128 ;(100.0)$ & $55.0 ;(100.0)$ & $86 ;(100.0)$ & $75.4 ;(100.0)$ \\
\hline $\begin{array}{l}\text { Species able to colonise } \\
\text { disturbed ground }\end{array}$ & $10 ;(7.5)$ & $0.6 ;(0.9)$ & $24 ;(18.7)$ & $4.7 ;(8.5)$ & $36 ;(41.9)$ & $50.3 ;(49.2)$ \\
\hline $\begin{array}{l}\text { Shrubs and species of } \\
\text { shrubby habitats }\end{array}$ & $12 ;(9.0)$ & $0.8 ;(1.3)$ & $8 ;(6.3)$ & $0.7 ;(1.2)$ & $3 ;(3.5)$ & $0.1 ;(0.1)$ \\
\hline $\begin{array}{l}\text { Species, which compose } \\
\text { the grass communities of } \\
\text { undisturbed ground }\end{array}$ & $111 ;(83.5)$ & $60.2 ;(97.8)$ & $96 ;(75.0)$ & 49.6; (90.3) & $47 ;(54.6)$ & $51.8 ;(50.7)$ \\
\hline Therophytes & $7 ;(5.3)$ & $0.1 ;(0.2)$ & $14 ;(10.9)$ & $0.6 ;(1.1)$ & $15 ;(17.5)$ & $23.9 ;(31.7)$ \\
\hline Hemicryptophytes & $107 ;(80.4)$ & $48.2 ;(78.4)$ & $102 ;(79.7)$ & $47.5 ;(86.3)$ & $61 ;(70.9)$ & $37.2 ;(49.3)$ \\
\hline Geophytes & $15 ;(11.3)$ & $12.6 ;(20.4)$ & $10 ;(7.8)$ & $6.6 ;(12,0)$ & $8 ;(9.3)$ & $14.3 ;(19.0)$ \\
\hline Chamaephytes & $2 ;(1.5)$ & $0.2 ;(0.3)$ & 0 & 0 & 0 & 0 \\
\hline Phanerophytes & $2 ;(1.5)$ & $0.5 ;(0.7)$ & $2 ;(1.6)$ & $0.3 ;(0.6)$ & $2 ;(2.3)$ & 0 \\
\hline Dicots & $113 ;(85.0)$ & $22.4 ;(36.3)$ & $111 ;(86.7)$ & $24.6 ;(44.8)$ & $73 ;(84.9)$ & $50.1 ;(66.5)$ \\
\hline Monocots & $20 ;(15.0)$ & $39.2 ;(63.7)$ & $17 ;(13.3)$ & $30.4 ;(55.2)$ & $13 ;(15.1)$ & $25.3 ;(33.5)$ \\
\hline Annual & $7 ;(5.3)$ & $0.1 ;(0.2)$ & $14 ;(10.9)$ & $0.6 ;(1.1)$ & $15 ;(17.4)$ & $23.9 ;(31.8)$ \\
\hline Biennial & $16 ;(12.0)$ & $0.3 ;(0.5)$ & $21 ;(16.4)$ & $1.6 ;(2.8)$ & 16 ; (18.6) & $5.6 ;(7.4)$ \\
\hline Perennial & $110 ;(82.7)$ & $61.2 ;(99.3)$ & $93 ;(72.7)$ & $52.8 ;(96.1)$ & $55 ;(64.0)$ & $45.9 ;(60.8)$ \\
\hline
\end{tabular}


nities among all the gullies, and so they were preferred for cattle grazing. However, there was a strong tendency for the percentage of typical inhabitants of disturbed vegetation to be greater in areas where grazing intensity had been historically heavy rather than moderate $(41.9 \%$ vs. $18.7 \%$, respectively, Table 3). These species (Carduus acanthoides, Cirsium vulgare, Capsella bursa-pastoris, Lepidium ruderale) have an annual or biennial life cycle, and immediately occupy bare soil. In heavily grazed gullies (including overgrazed ones), the proportion and coverage of therophytes number was the highest. Dicots dominated in terms of number of species in all the gullies, but monocots dominated in terms of cover scores in lightly and moderately grazed gullies. Dicots dominated in terms of cover in heavy grazed gullies, mainly due to the overgrazed patches (Table 3).

The percentage cover of grasses showed a tendency to be higher in areas where heavy grazing caused the exclusion of steppe bunch grasses by loose-bunch grasses $(74 \pm 15 \%$ vs. $46 \pm 12 \%)$ (Table 2$)$. The maximum vegetation height was lowest in overgrazed areas (e.g., $5 \pm 1 \mathrm{~cm}$ in cover of Polygonum aviculare in mid summer). Under moderate grazing, this value was also low (e.g., $7 \pm 2 \mathrm{~cm}$ in cover of Festuca valesiaca at the same time) in comparison with the vegetation under light grazing. $(15 \pm 6 \mathrm{~cm}$ in cover of Festuca valesiaca at the same time).

According to our observations, the effects of abandonment were different and depended on previous stage of pasture degradation as well as on habitat humidity. For example, the overgrazed plots (the latest stage of pasture degradation) became overgrown with Carduus acanthoides. Its height in the first years after abandonment exceeded $2 \mathrm{~m}$ in moist places; and $1 \mathrm{~m}$ in dry places. The community dominated by Agrimonia eupatoria appeared in all habitats that were not too dry after three to five years of abandonment on late and mid stages of pasture degradation. Abandonment after the early stage of pasture degradation caused the community of Stipa capillata+Festuca valesiaca to redevelop on dry places, and the community of Galatella villosa on washed chernozem soils.

The total number of available grass communities per gully increased (7 vs. 5) when moderate grazing changed to light grazing. Simultaneously, a higher abundance of large-flowered forbs was observed. After 15 years without cattle grazing in one of the lightly grazed gullies, seven species from the previous list were absent, and the abundance of several large-flowered forbs (Adonis vernalis, $R a-$ nunculus illyricus, Silene viscosa, Phlomis tuberosa, Salvia nemorosa, Lavatera thuringiaca, Verbascum austriacum etc.) was diminished. On the contrary, abundance of shrubs (Rosa canina, R. tesquicola) and trees (Pyrus communis, Malus domestica) increased radically. The trees be- gan to colonize the gully bottoms throughout the study site after abandonment immediately. But typical steppe species (Stipa lessingiana, S. pennata, S. pulcherrima, S. tirsa), which were gradually appearing as free-standing individuals, began to form feather grass communities only after $10-12$ years without cattle grazing.

\section{Study site "Dvorichanskyi"}

\section{Flora and vegetation}

The park is characterised by chalky outcrops with unique vegetation. Communities of meadows and forb-fescuefeather grass steppe that occupy areas with mature soil are also represented in the park. On the permanent study plot, 211 species of vascular plants were registered. This list includes grasses, forbs and steppe shrubs. According to humidity variation, four ecological groups are present in the chalky gullies; the majority of species (111 species) were xeromesophytes (Figure 7). In addition to the list of species that characterised typical gully steppe of the study area (as mentioned above), 58 species and 48 genera from 27 families represent the vegetation of the chalky outcrops and the chalky steppe. The majority of dicot species in the list of the chalky habitats belonged to the following families: Fabaceae (8), Brassicaceae (6), Asteraceae (5), Lamiaceae (5). There were $63 \mathrm{rare}$ and/or protected species (17 are listed in the Red Book of Ukraine). Among these rare plants, we found 14 endemics of the chalky outcrops of the Siverskyi Donets basin.

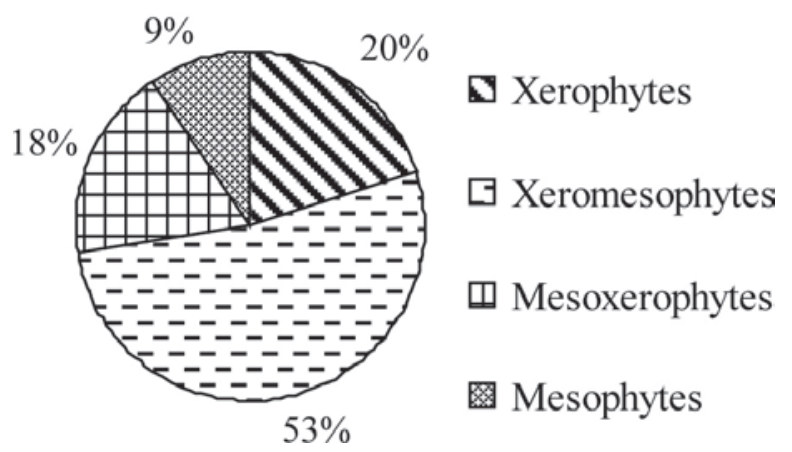

Figure 7: The proportion of different ecological groups according to humidity variation in the gullies of the permanent study plot "Dvorichanskyi".

Slika 7: Delež različnih ekoloških skupin na podlagi variabilnosti vlažnosti v jarkih na stalnih poskusnih ploskvah v "Dvorichanskyi"

The vegetation of chalky outcrops is characterised by two original types of phytocoenoses: 1). Open communities dominated by cretaceous species of dwarf subshrubs, mainly Artemisia hololeuca, Thymus cretaceus, Hyssopus cretaceus and Scrophularia cretacea; Matthiola fragrans, Helianthemum cretaceum, Hedysarum grandiflorum, and 
other rare species are common here. 2). Thyme calcareous-steppe. This dry grassland contains the steppe graminoids Stipa capillata, S. lessingiana, S. pennata and S. pulcherrima, Bromopsis riparia, Festuca rupicola, F. valesiaca, Koeleria cristata, the sedge Carex humilis and the forbs Astragalus albicaulis, $A$. onobrychis, $A$. austriacus, Teucrium polium, Polygala cretacea, Onosma tanaitica, Salvia nutans, Galatella linosyris etc.

\section{Effects of natural erosion and grazing on the vegetation of chalky outcrops}

Till the beginning of 1990s, cattle grazing on chalky outcrops increased the natural erosion of the chalky slopes. In contrast to the areas with mature soil, the grazing on the chalky slopes was sporadic. At the start of the study in the early 2000s, the steppe pastures on the slopes with chalky subsoil were abandoned for about 10 years. Among the plant combinations of the chalk steppe, Stipa capillata+Salvia nutans, Stipa capillata+Galatella linosyris, Stipa capillata+Festuca rupicola, Carex humilis+Centaurea marschalliana, Stipa capillata+seasonally changing dominant forbs were common. Natural erosion of the chalk was the basic factor that determined the distribution and presence of chalk flora. All stages of the succession were observed - from pioneer species stage on pure chalk to steppe communities on mature soil.

The pioneers of pure creeping chalk are Artemisia hololeuca, Matthiola fragrans, Thymus cretaceus, Hyssopus cretaceus and other typical cretaceous species. The vascular plants make up less than $10 \%$ of the living cover in the beginning, with the number of species on $1 \mathrm{~m}^{2}$ varying from 6 to 10 (Table 4).

Table 4: Typical plant community of permanent study plot "Dvorichanskyi" in 2001-2014: their dominant species, cover values, number of species, and diversity indexes.

Tabela 4: Značilne rastlinske združbe na stalni poskusni ploskvi "Dvorichanskyi” med leti 2001 in 2014: dominantne vrste, pokrovne vrednosti, število vrst in indeksi raznolikosti.

\begin{tabular}{|c|c|c|c|c|c|c|}
\hline $\begin{array}{l}\text { Degree of soil } \\
\text { development on } \\
\text { chalky outcrops } \\
\end{array}$ & $\begin{array}{l}\text { Vascular plant } \\
\text { living cover, } \\
\text { mean } \pm \text { s.d., } \%\end{array}$ & $\begin{array}{l}\text { Dominant species and } \\
\text { their percentage cover, } \\
\text { mean } \pm \text { s.d., } \%\end{array}$ & $\begin{array}{l}\text { Total number of } \\
\text { species; (mean per } \\
\left.1 \mathrm{~m}^{2} ; 10 ; 100 \mathrm{~m}^{2}\right)\end{array}$ & $\begin{array}{c}\text { № of layers; } \\
\text { maximum vegetation } \\
\text { height, } \mathrm{x} \pm \text { s.d., } \mathrm{cm}\end{array}$ & $\begin{array}{l}\text { Shannon' } \\
\text { index }\end{array}$ & $\begin{array}{l}\text { Margalef } \\
\text { index }\end{array}$ \\
\hline White creeping chalk* & $7 \pm 3$ & $\begin{array}{l}\text { Artemisia hololeuca; } \\
\qquad 4 \pm 2\end{array}$ & $23 ;(10 ; 13 ; 17)$ & $1 ; 10 \pm 7$ & 1.752 & 6.913 \\
\hline $\begin{array}{l}\text { White slow-creeping } \\
\text { chalk }\end{array}$ & $19 \pm 6$ & $\begin{array}{l}\text { Artemisia hololeuca }+ \\
\text { Thymus cretaceus; } \\
18 \pm 5\end{array}$ & $42 ;(12 ; 23 ; 25)$ & $1 ; 19 \pm 4$ & 1.182 & 7.210 \\
\hline $\begin{array}{l}\text { Grey chalk, } \\
\text { total living cover } \\
\text { less than } 50 \%\end{array}$ & $45 \pm 6$ & $\begin{array}{l}\text { Hedysarum grandiflorum; } \\
\qquad 21 \pm 4\end{array}$ & $50 ;(13 ; 18 ; 25)$ & $2 ; 33 \pm 7$ & 2.016 & 9.060 \\
\hline $\begin{array}{l}\text { Grey chalk, } \\
\text { total living cover } \\
\text { less than } 50 \%\end{array}$ & $30 \pm 10$ & $\begin{array}{l}\text { Astragalus albicaulis; } \\
\qquad 11 \pm 5\end{array}$ & $69 ;(16 ; 25 ; 37)$ & $2 ; 56 \pm 10$ & 2.425 & 12.086 \\
\hline $\begin{array}{l}\text { Grey chalk, } \\
\text { total living cover } \\
\text { less than } 50 \%\end{array}$ & $37 \pm 8$ & $\begin{array}{c}\text { Stipa pennata + Carex humilis }+ \\
\text { Bromopsis riparia }+ \text { Centaurea } \\
\text { marschalliana } ; 11 \pm 5\end{array}$ & $70 ;(25 ; 38 ; 47)$ & $3 ; 59 \pm 8$ & 3.405 & 13.259 \\
\hline $\begin{array}{l}\text { Grey chalk, } \\
\text { total living cover } \\
\text { more than } 50 \%\end{array}$ & $58 \pm 4$ & $\begin{array}{l}\text { Astragalus albicaulis; } \\
\qquad 15 \pm 7\end{array}$ & $72 ;(21 ; 32 ; 43)$ & $2 ; 44 \pm 14$ & 3.226 & 12.995 \\
\hline $\begin{array}{l}\text { Grey chalk, } \\
\text { total living cover } \\
\text { more than } 50 \%\end{array}$ & $58 \pm 9$ & $\begin{array}{c}\text { Carex humilis }+ \\
\text { Thymus marschallianus; } \\
24 \pm 11\end{array}$ & $64 ;(19 ; 36 ; 43)$ & $2 ; 25 \pm 7$ & 3.090 & 10.746 \\
\hline $\begin{array}{l}\text { Grey chalk, } \\
\text { total living cover } \\
\text { more than } 50 \%\end{array}$ & $60 \pm 8$ & $\begin{array}{l}\text { Stipa pulcherrima }+ \\
\text { Inula aspera; } \\
37 \pm 16\end{array}$ & $52 ;(13 ; 20 ; 31)$ & $2 ; 53 \pm 8$ & 2.343 & 9.806 \\
\hline $\begin{array}{l}\text { Chalk covered with } \\
\text { slight layer of soil }\end{array}$ & $74 \pm 12$ & $\begin{array}{c}\text { Stipa pennata }+ \\
\text { Carex humilis }+ \\
\text { Centaurea marschalliana; } \\
11 \pm 4\end{array}$ & $81 ;(28 ; 44 ; 55)$ & $3 ; 60 \pm 11$ & 3.672 & 14.051 \\
\hline
\end{tabular}

${ }^{*}$ In each row $\mathrm{n}=6$. 
Then, the vascular plant living cover increases to $10-25 \%$, while the number of species per $\mathrm{m}^{2}$ increases to 8-12; Hedysarum grandiflorum and species of genus Stipa can already be present in the vegetation. The growth of Thymus cretaceus, Helianthemum cretaceum or Hedysarum grandiflorum significantly increases the vegetation density, but decreases the presence of Artemisia hololeuca. Disappearance of Matthiola fragrans is simultaneously observed.

Increased presence and density of the Fabaceae species Hedysarum grandiflorum or Astragalus albicaulis with additional graminoids (Carex humilis, species of genus Sti$p a)$ indicates the initial stage of steppe soil development. The vascular plant living cover is $25-50 \%$; the number of species per $\mathrm{m}^{2}$ varies from 13 to 25 (Table 4).

True thyme steppe communities can be found at the areas where at least a thin layer of soil covers a chalk. Their vascular plant living cover ranges from $35-50 \%$ to $60-70 \%$, the number of species in such areas varies from $15-19$ to over 30 per $\mathrm{m}^{2}$, but the diversity of typical cretaceous species is reduced (Table 5); these plants occupy mainly uncovered chalk.

On the permanent study plot, pure Artemisia hololeuca or Artemisia hololeuca+Thymus cretaceus or Artemisia hololeuca+Hyssopus cretaceus form a monotonous silver-grey sparse sward whereas patches dominated by Thymus cretaceus and Hyssopus cretaceus are more varied and colourful. Large stands dominated by Hedysarum grandiflorum are rare and occupy small areas. Among communities of the chalk steppe Stipa pennata+Carex humilis+Centaurea marschalliana, Carex humilis+Thymus marschallianus, Stipa pulcherrima+Inula aspera are registered (Table 4).

Recently, the expansion of shrubs (Rosa villosa, Crataegus monogyna, Berberis vulgaris, Swida sanguinea, Prunus spinosa, Viburnum opulus etc.) and trees (especially Pinus sylvestris) has been observed. The north facing slopes and the gully bottoms with at least a thin layer of soil are most intensively colonized. Pinus sylvestris successfully germinates and survives on the chalky crumb. Carduus acanthoides, Cyclachaena xanthifolia and other species typical of nutrient-rich soils are sometimes abundant at the bottoms of chalky slopes that adjoin to bottomlandmeadow.

The bottomland-meadow occupied by communities of Poa angustifolia, P. pratensis and Elymus repens was grazed till the 2000s, but grazing pressure became light after the early 1990s. Recently, two small plots of the meadow regularly have light grazing pressure. Since abandonment of grazing, the abundance of shrubs and trees (especially, Pyrus communis) as well as the species typical of nutrient-rich soils increased significantly.

\section{Discussion}

Dengler et al. (2014) presented a synthesis of the current knowledge on anthropogenic influences on diversity in different grasslands. Steppe grasslands developed and persisted through the activities of large herbivores (Dinesman 1977). In the steppe zone, species richness varied significantly with grazing pressure (e.g., Cheng et al. 2011), and this pattern was also confirmed by our study. Our results confirm that heavy grazing increases therophytes and decreases the proportion of chamaephytes and phanerophytes. Besides, heavy grazed plots have high proportion of species which have ability to occupy disturbed ground. This species group includes mainly the species with regeneration by means of a persistent seed bank (see also Dupré \& Diekmann 2001, Škornik et al. 2010).

According to our observations, moderate and rotational cattle grazing maintains the medium stage of the degradation-recovery process of vegetation development. After cessation of moderate grazing, the vegetation becomes the most picturesque and diverse in forb species.

Table 5: Proportion of ecologically different species according to the degree of soil development on chalky outcrops in the gullies of permanent study plot "Dvorichanskyi" (200 hectares) in 2001-2014.

Table 5: Delež ekološko različnih vrst glede na stopnjo razvoja tal na apnenčastih izdankih v jarkih na stalni poskusni ploskvi "Dvorichanskyi" (200 hektarjev) med letoma 2001 in 2014.

\begin{tabular}{lcccc}
$\begin{array}{l}\text { Degree of soil development on } \\
\text { chalky outcrops }\end{array}$ & \multicolumn{3}{c}{ Number of species; and percent } \\
White creeping chalk & $4 ; 17.4$ & $1 ; 4.3$ & $18 ; 78.3$ & $16 ; 69.6$ \\
White slow-creeping chalk & $4 ; 10.8$ & $2 ; 5.4$ & $31 ; 83.8$ & $18 ; 48.6$ \\
Grey chalk, living cover less than 50\% & $7 ; 7.1$ & $8 ; 8.1$ & $84 ; 84.8$ & $18 ; 18.2$ \\
Grey chalk, living cover more than 50\% & $6 ; 5.0$ & $9 ; 7.5$ & $105 ; 87.5$ & $11 ; 9.2$ \\
Chalk covered with a thin layer of soil, living cover more than $50 \%$ & $2 ; 1.5$ & $7 ; 5.3$ & $123 ; 93.2$ & $8 ; 6.1$ \\
\hline
\end{tabular}


There the abundance of Amygdalus nana, Adonis vernalis, Pulsatilla pratensis subsp. nigricans, Hyacinthella leucophaea, Phlomis tuberosa, Salvia nemorosa, S. austriaca, S. stepposa, Verbascum austriacum, Viola hirta increases significantly. This species group includes mainly the species with low competitive strategy. The changes in floristic structure are caused by suppression of the dominant species by the grazing factor (i.e., due to reduced competitive exclusion). So, moderate grazing promotes plant diversity in steppe ecosystems (see also Török et al. 2014). Compared with the initial biodiversity, uneven distribution of grazing intensity on the vegetation of gullies caused an increase in number of both plant communities and species (10 vs. 6 , and 210 vs. 133 , respectively). The presence of species and plant communities of different successional stages in combination with the original communities increases biological diversity. The initial mosaic of plant communities is amplified with vegetation at different stages of both pasture degradation and recovery process. This is the result increased habitat heterogeneity through variation in grazing and trampling of the livestock. Varying grazing should allow more species to coexist than under other more homogeneous influences (reviewed by Dengler et al. 2014).

To sustain populations of plants and animals with diverse environmental requirements, a mosaic system including various intensities of grazing in space and time is required. Some herbivores (marmots, saiga antelopes, sousliks) are the secondary inhabitants of steppe pastures and the satellites of large ungulates. For example, the success of the steppe marmot (Marmota bobak) population is determined by the vegetation accompanying the late stage of pasture degradation. The vegetation at this stage has high proportions of legumes (on moist places on gully bottoms), rosette-forming and perennial fodder species. The basic food species of the marmots, i.e. the plants eaten by the animals during all the active season, are species that are abundant only in the heavy grazed areas (Ronkin \& Savchenko 2004, Ronkin et al. 2009). But feather grass communities are destroyed after the early stage of pasture degradation. To combine the steppe biota, heterogeneous grazing (including areas without grazing) in space and time is necessary. It provides habitat heterogeneity and increase of diversity at a landscape scale. To maintain a rich species diversity, the management in different grassland types should be carried out according to traditional management and with a zonation regime, as it is suggested by Vassilev et al. (2011).

In chalky landscapes, the effect of habitat heterogeneity is achieved by natural erosion and soil development processes of chalky outcrops. Mature, deeper soils support fewer typical cretaceous species, as such plants re- quire bare, unstable chalk. These species fix the chalk and then are excluded by species with a more competitive strategy. Thus, the areas without steppe soils are also necessary for the preservation of biodiversity. At present, this is provided by the natural erosion of chalky outcrops (in the past, grazing probably significantly increased erosion). Maintaining these areas in the condition of creeping soilless chalk not covered by steppe soils remains one of the problems for chalk landscape conservation in the future.

The second problem of grassland conservation is the encroachment of trees. This tendency is observed especially on the north-facing slopes and meadows of gully bottoms. This is a serious problem, as tree invasion means a dramatic change in grassland ecosystems: shading and competition by woody plants exclude several light-demanding grassland species, which results in decreased biodiversity (see Valkó et al. 2011, Carboni et al. 2015). Woody encroachment is a general process in the natural succession of many types of grasslands after abandonment (Helm et al. 2006, Vassilev et al. 2011, reviewed by Janišová et al. 2011, Giarrizzo et al. 2015).

\section{Conclusions}

According to our results, the changes in floristic structure at a plot scale are caused by suppression of the dominant species by grazing. Heterogeneity of grazing (including ungrazed areas and abandonment) in space and time provides diversity at a landscape scale. Lack of grazing and long-lasting abandonment promote feather grass communities; light and moderate grazing promotes plant species with a low competitive strategy. Heavy grazing favours species with regeneration by means of a persistent seed bank, and promotes secondary inhabitants of steppe pastures (such as the steppe marmot). Thus, heterogeneous grazing is necessary in order to preserve both the biodiversity of the grasslands and the presence of species of steppe fauna in the ecosystem.

Communities with the highest proportion of typical cretaceous species occupy white creeping and slow-creeping chalk. During early soil development on the chalky outcrops, the abundance of the cretaceous species decreases. Other communities peculiar to chalk steppe correspond to these stages. The presence of different degrees of soil development on the chalky outcrops increases biodiversity. The erosion of chalky outcrops (natural erosion as well as driven by cattle grazing) supports the different stages of soil development of the chalky outcrop. Erosion is a key factor that enriches the steppe grassland with species of chalk habitats. 


\section{Acknowledgments}

The authors are grateful to Michał Żmihorski (Museum and Institute of Zoology Polish Academy of Sciences), Laura Sutcliffe (Plant Ecology and Ecosystem Research, Georg-August University of Göttingen, Germany) and two anonymous reviewers for the English proofreading, editing the manuscript and for the recommendations, comments and improvements of former drafts of the paper.

\section{References}

Bagalii, D. I. 1918: Istoria Slobodskoi Ukraini (History of Slobodska Ukraine). Kharkiv: Delta Press, 256 pp. [In Ukrainian].

Carboni, M., Dengler, J., Mantilla-Contreras, J., Venn, S. \& Török, P. 2015: Conservation value, management and restoration of Europe's semi-natural open landscapes. Hacquetia 14: 5-17.

Cheng, Y., Tsubo, M., Ito, T. Y., Nishihara, E. \& Shinoda, M. 2011: Impact of rainfall variability and grazing pressure on plant diversity in Mongolian grasslands. Journal of Arid Environments 75: 471-476.

Dengler, J., Janišová, M., Török, P. \& Wellstein, C. 2014: Biodiversity of Palaearctic grasslands: a synthesis. Agriculture, Ecosystems \& Environment 182: 1-14.

Dinesman, L.G. 1977: Biogeotsenozi stepey v golotsene (Steppe ecosystems in Holocene). Nauka, Moskva, 159 pp. [In Russian].

Dupré, C. \& Diekmann, M. 2001: Differences in species richness and life-history traits between grazed and abandoned grasslands in southern Sweden. Ecography 24: 275-286.

Giarrizzo, E., Burrascano, S., Zavattero, L. \& Blasi, C. 2015: New methodological insights for the assessment of temporal changes in semi- natural dry grasslands plant species composition based on field data from the northern Apennines. Hacquetia 14: 19-32.

Gorelova, L. N. 2002: Rastitelnii pokrov Kharkovshchini (Plant cover of Kharkov Region). Kharkiv: Karazin National University Press, 231 pp. [In Russian].

Güldenstaedt, A. 1774: Dnevnik puteshestvia po SlobodskoUkrainskoi gubernii Akademica S-Peterburgskoi Akademii Nauk Gildenshtedta v avguste i sentiabre $1774 \mathrm{~g}$. (Journal of travel of member of St. Petersburg Academy of Sciences, Güldenstädt, in Slobodska-Ukrainian province in August and September 1774). Kharkiv, 88 pp. [In Russian].
Helm, A., Hanski, I. \& Pärtel, M. 2006: Slow response of plant species richness to habitat loss and fragmentation. Ecology Letters 9: 72-77.

Janišová, M., Bartha, S., Kiehl, K. \& Dengler, J. 2011: Advances in the conservation of dry grasslands - introduction to contributions from the 7th European Dry Grassland Meeting. Plant Biosystems 145: 507-513.

Levina, F. 1933: Zalyshky zilynnoi stepovoi roslynnosti na Kupianshchine u Velykoburluzkomu raioni (Remnants of virgin steppe vegetation in Kupiansk and Velykyi Burluk regions). Journal du Cycle botanique de l'Academie des Sciences d'Ukraine 5-6: 183-199. [In Ukrainian].

Ramensky, L. G. 1971: Problemi i metodi izucheniya rastitelnogo pokrova (Problems and methods of a study of vegetation cover). Nauka, Leningrad, 336 pp. [In Russian].

Ronkin, V. I. \& Savchenko, G. A. 2004: Effect of cattle grazing on habitats for the steppe marmot (Marmota bobak) in north-eastern Ukraine. Vestnik zoologii 38 (1): 55-60.

Ronkin, V., Savchenko, G. \& Tokarsky, V. 2009: The place of the steppe marmot in steppe ecosystems of Ukraine: an historical approach. Ethology Ecology \& Evolution 21: 277-284.

Škornik, S., Vidrih, M. \& Kaligarič, M. 2010: The effect of grazing pressure on species richness, composition and productivity in North Adriatic Karst pastures. Plant Biosystems 144: 355-364.

Török, P., Valkó, O., Deák, B., Kelemen, A. \& Tóthmérész, B. 2014: Traditional cattle grazing in a mosaic alkali landscape: Effects on grassland biodiversity along a moisture gradient. PLoS ONE 9 (5): e97095.

Ugrinsky, K. A. 1918: Spisok bolee redkih rasteniy, sobrannih v Volchanskom uezde Kharkovskoy gubernii v 1916-1917 godu (A list of more rare plant species collected in Volchansk district of Kharkov province in 1916-1917). Sinelnikovo: G. L. Satanovky Press, 27 pp. [In Russian].

Valkó, O., Török, P., Tóthmérész, B. \& Matus, G. 2011: Restoration potential in seed banks of acidic fen and dry-mesophilous meadows: Can restoration be based on local seed banks? Restoration Ecology 19: $9-15$.

Vassilev, K., Pedashenko, H., Nikolov, S.C., Apostolova, I. \& Dengler, J. 2011: Effect of land abandonment on the vegetation of upland semi-natural grasslands in the Western Balkan Mts., Bulgaria. Plant Biosystems 145: 654-665.

Zhivotnovodstvo SSSR za 1916-1938 gg., 1940: (Livestock farming of USSR in 1916-1938). Moskva-Leningrad: Gosplanizdat, 219 pp. [In Russian]. 